\title{
Epicardial adipose tissue, intramyocardial fat and right heart morphology: histopathological analysis
}

\author{
Kristina Selthofer-Relatićc ${ }^{*}$, Jasmina Rajc', Boris Dumenčić', Ivica Bošnjak1, Radivoje Radić \\ Robert Steiner', Domagoj Boban' \\ 'University Hospital Centre Osijek, Osijek, Croatia \\ ${ }^{2}$ School of Medicine, University J. J. Strossmayer Osijek, Osijek, Croatia
}

\begin{abstract}
Epicardial adipose tissue represents cardiometabolic risk factor. It is a fat deposit around the heart, predominantly over the right ventricle free wall and specially apex, posseses the same microcirculation as myocardium, induces inflammation and endothelial dysfunction via the "inside out" pathway by adipocytokines and free fatty acids: inflammatory intima cell infiltration, transcytosis of cholesterol rich lipoproteins, oxidative modification, foam cell formation and smooth muscle cell proloferation. According to recent studies with cardiac imaging (computed tomography and magnetic resonance), intramyocardial fat was found in the right ventricle free wall in physiologic (ageing) and pathophysiologic (arrhythmogenic right ventricle dysplasia) conditions, as the connective tissue between cardiomyocytes, not as cardiomyocytes hypertrophy. The origin and types of intramyocardial fat, its connection to epicardial adipose tissue and their effect on the right atrium/ventricle morphology and function is not clear yet. The latest reports referred the potential impact of epicardial fat on the right/left atrium with differences in remodeling and arrhytmogenesis. The purpose of this prospective study was to investigate the correlation between epicardial adipose tissue and intramyocardial fat with right atrium/ventricle morphology in persons with/ without cardiovascular diseases on autopsy. Depending on
\end{abstract}

the degree of cardiac visceral obesity respectively epicardial adipose tissue, we assume that the excessive fat accumulation will cause the accumulation of fat cells into the right atrium and right ventricle free wall with subsequent remodeling.

KEYWORDS: epicardial adipose tissue, intramyocardial fat, obesity, right atrium, right ventricle.

CITATION: Cardiol Croat. 2013;8(9):314.

Received: $30^{\text {th }}$ Jun 2013

*Address for correspondence: Klinički bolnički centar Osijek, J. Huttlera 4, HR31000 Osijek, Croatia.

Phone: +385-31-511-717

E-mail: selthofer.relatic@gmail.com

\section{Literature}

1. Nelson MR, Mookadam F, Thota V, et al. Epicardial fat: an aditional measurement for subclinical atherosclerosis and cardiovascular risk stratification? J Am Soc Echocardiography. 2011;24(3):339-45.

2. Kimura F, Matssuo Y, Nakajima T, et al. Myocardial fat at cardiac imaging: how can we differentiate pathologic from physiologic fatty infiltration? Radiographics. 2010;30:1587602.

3. Lin YK, Chen YC, Chang SL, et al. Heart failure epicardial fat increases atrial arrhythmogenesis. Int J Cardiol. 2012 May 25. [Epub ahead of print] 